\title{
Anyagtudósok kalandozása a biológiában: A lepkék szárnyainak szerkezeti színei
}

\section{Roaming of Materials Scientists in Biology: Structural Colours of Butterfly Wings}

\author{
Biró László Péter, ${ }^{1}$ Kertész Krisztián, ${ }^{1}$ Piszter Gábor, ${ }^{1}$ Horváth Zsolt Endre, ${ }^{1}$ Bálint Zsolt ${ }^{2}$ \\ ${ }^{1}$ Müszaki Fizikai és Anyagtudományi Intézet, Energiatudományi Kutatóközpont, Magyar Tudományos \\ Akadémia, Budapest, Magyarország, biro.laszlo@energia.mta.hu \\ ${ }^{2}$ Magyar Természettudományi Múzeum, Budapest, Magyarország, balint.zsolt@nhmus.hu
}

\begin{abstract}
The photonic nanoarchitectures occurring in the wing scales of lycaenid butterflies were investigated by scanning electron microscopy (SEM), transmission electron microscopy (TEM) and UV-VIS spectroscopy. We found that the males of all the nine investigated species possess photonic nanoarchitectures built according to the same general "plan", but each species exhibits species-specific features which results in species-specific colours reproduced generation by generation with a high degree of accuracy.
\end{abstract}

Keywords: butterfly wing scales, photonic nanoarchitecture, electron microscopy, UV-VIS spectroscopy.

\section{Összefoglalás}

Pásztázó elektronmikroszkóppal (SEM), transzmissziós elektronmikroszkóppal (TEM) és UV-VIS spektroszkópiával vizsgáltuk a boglárkalepkék szárnypikkelyeiben előforduló fotonikus nanoarchitektúrákat. Megállapítottuk, hogy mind a kilenc megvizsgált faj hímjeinek azonos szerkezeti rendszer szerint felépülő fotonikus nanoarchitektúrájúak a szárnypikkelyeik, de minden egyes faj elégséges mértékű faji sajátosságokat mutat a fajspecifikus színek létrejöttéhez. Ezek a színek nagy pontossággal reprodukálódnak generációról generációra.

Kulcsszavak: lepkék szárnypikkelyei, fotonikus nanoarchitektúra, elektronmikroszkópia, UV-VIS spektroszkópia.

\section{Bevezető a fotonikus nanoarchitek- túrákról}

\subsection{A fizika felöl nézve}

A fizika mintegy harminc évvel ezelőtt fedezte fel, hogy a fényhullámok esetében is előidézhető a félvezetők esetében jól ismert tiltott sáv megjelenése [1, 2]. Ehhez az szükséges, hogy olyan kompozitot állítsunk elő, amely két eléggé eltérő törésmutatójú, átlátszó közegből épül fel, és a törésmutató értékei periodikusan váltakoznak a térben olyan skálán, amely összemérhető a kompozitban terjedni nem képes fény hullámhosszá- val. Ez utóbbi feltételből adódik, hogy a látható fény tartományában a fent említett kompozit tulajdonképpen egy nanokompozit, azaz a törésmutató váltakozása tipikusan 100 nm-es skálán történik. Ha szigorúan értelmezzük a fenti feltételeket, akkor az azoknak megfelelően létrejövő nanoarchitektúra egy fotonikus kristály lesz, amelyben az adott hullámhosszúságú fény semmilyen irányban sem tud terjedni, ezért visszaverődik a fotonikus kristály felszínéről. Ha lazítunk a tökéletes rendezettség feltételén, a fotonikus tiltott sáv megmarad és spektrális helyzetét is megőrzi, azonban szélessége csökken, és a teljes tiltott sáv részleges tiltott sávvá alakulhat át [3]. 


\subsection{A biológia felől nézve}

A biológiai evolúció mintegy ötvenmillió évvel ezelőtt fedezte fel a fotonikus nanoarchitektúrákban rejlő lehetőségeket [4]. Azóta is számos élőlény alkalmazza ezt a színképzési mechanizmust változatos biológiai funkciók megvalósítására. A legközismertebb példák a lepkék és a különféle bogarak között adódnak [5]. A lepkék esetében a kék és zöld színek leggyakrabban szerkezeti eredetűek, azaz fotonikus nanoarchitektúrákra vezethetők vissza. A kék szín és ennek különféle árnyalatai különösen alkalmasak a figyelem felkeltésére például egy mező zöld háttere előtt [6]. Az ilyen jellegű élőhelyen élő boglárkalepkék hímjei a kék különböző árnyalataiban pompáznak, míg a nőstények szárnyfelszíne rendszerint festékanyag (melanin) által színezett barna. Ez azt eredményezi, hogy a nőstények szárnyai hatékonyabban nyelik el a napsugárzást [7], és ez elősegíti a felmelegedésüket, ami hasznos a peték érleléséhez.

\subsection{Az anyagtudomány felől nézve}

Ha az anyagtudomány felől tekintjük a szerkezeti (fizikai) színeket előállító nanoarchitektúrákat, akkor az első tényező, amit ki kell emelnünk, az a kompozitot felépítő két átlátszó anyag törésmutatójának elégséges különbsége. Minél nagyobb ez a különbség, annál könnyebben alakul ki fotonikus tiltott sáv, ha a két összetevő megfelelő periodicitással váltogatja egymást. A lepkék - a jelen írás fókuszában található rovarok - esetében a két összetevő a kitin, amelynek törésmutatója $\mathrm{n}_{1}=1,56$ és a levegő, amelynek törésmutatója $\mathrm{n}_{2}=1$. A kitin egy biológiai polimer, egy poliszacharid, amelynek képlete és tulajdonságai közel állnak a cellulóz, a papír alapanyagát képező anyag tulajdonságaihoz.

Az eddigiekből következik, hogy a kitint és a levegőt 100 nm-es skálán kell „összekevernünk” egymással ahhoz, hogy a keletkező nanokompozit szerkezeti színt hozzon létre.

Természetesen ennek az összekeverésnek különféle módozatai lehetségesek: a) a $100 \mathrm{~nm}$-es skálát jóval meghaladó méretben tökéletesen periodikus összekeverés, amit fotonikus egykristálynak nevezünk [8]; b) mikrométeres skálán tökéletesen periodikus szemcsékből felépülő úgynevezett fotonikus polikristály, amelynek a szemcséi véletlenszerüen el vannak forgatva egymáshoz viszonyítva [8]; c) csak közelrendezettséget mutató, úgynevezett fotonikus amorf, amelynek építőelemei között csak rövid távon fedezhető fel valamilyen rend, például az első szomszédok átlagosan ugyanakkora távolságra vannak egymástól [9]. Ez utóbbi esetre mutat példát az 1. ábra.

Jól megfigyelhető az 1. ábrán, hogy a pikkelyek szabályos rendben helyezkednek el a lepkeszárnyon, azt az elrendezést idézve, ahogyan a cserepek borítják a háztetőt. Jellemző méreteik $100 \times 50 \mu \mathrm{m}^{2}$, alakjuk pedig egy lapított zsákot idéz, amelynek vastagsága $1 \mu \mathrm{m}$. Ez az a térfogat, amelyet kitölt a fotonikus nanoarchitektúra.

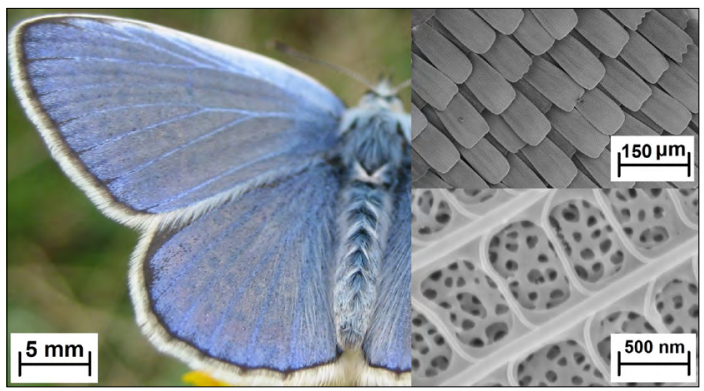

1. ábra. Hím Ikarusz boglárka (Polyommatus icarus) szárnyfelszínének fényképe balra), pikkelyeinek (jobbra fent) és a pikkelyekben található nanoarchitektúrának (jobbra lent) pásztázó elektronmikroszkópos felvétele

\section{Szexuális jelzőszín}

A boglárkalepke-félék körében igen gyakori az ivari kétalakúság, azaz a hímnek és a nősténynek teljesen más a megjelenési formája.A hímekszárnyfelszíne kékes árnyalatú, és ezt szerkezeti eredetű szín okozza (2. ábra [6]), míg a nőstények szárnyfelszíne pigment eredetű barna. Mindkét ivar szárny fonákján ugyanolyan, a fajra jellemző, de a fajok között sok hasonlóságot mutató bonyolult, ugyancsak pigment alapú pontmintázat található.

\section{A színeket létrehozó nanoarchitek- túrák}

A fajra jellemző szexuális jelzőszíneket azonos elvek alapján felépülő, de mégis az egyes fajokra jellemző kialakítású nanoarchitektúrák hozzák létre. Méretükből adódóan ezeknek a nanokompozitoknak a jellemzői csak elektronmikroszkópos módszerekkel tárhatók fel. Az egyes pikkelyek felszínéről pásztázó elektronmikroszkóppal (SEM) (3. ábra), míg a pikkelyek keresztmetszeti szerkezetéről transzmissziós elektronmikroszkóppal (TEM) nyerhetők adatok (4. ábra). Ez utóbbi módszer alkalmazásához az szükséges, hogy a speciális polimerbe ágyazott lepkeszárnyból 70 nm vastagságú szeleteket vágjunk gyémánt ultramikrotom késsel. 


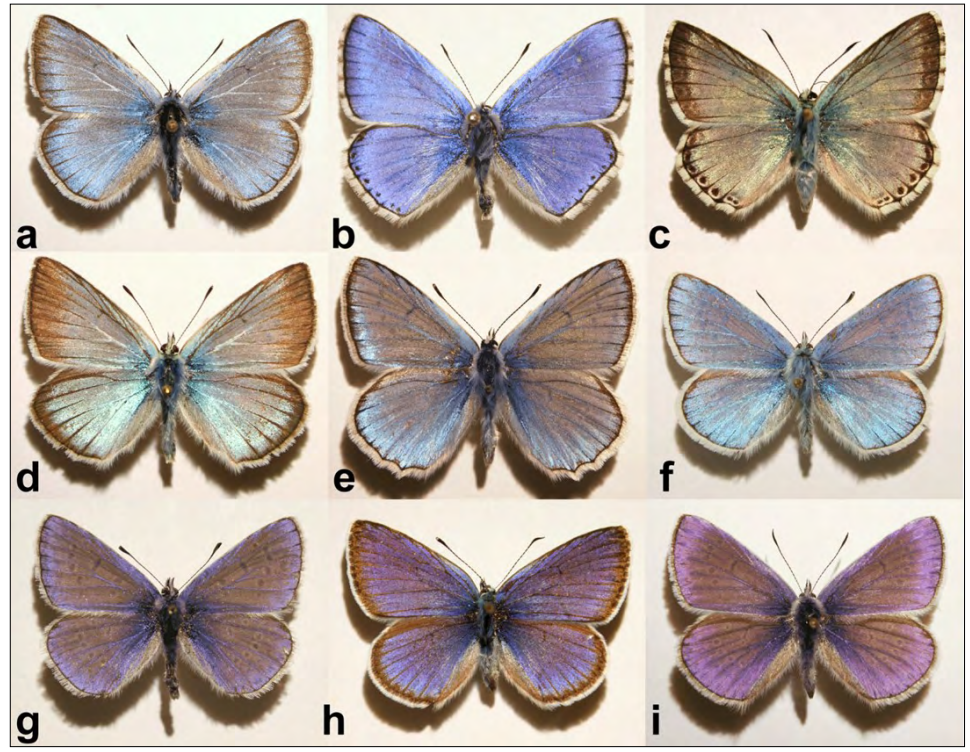

2. ábra. Kilenc, azonos élőhelyen előforduló közeli rokon boglárkafaj hímjeiröl, azonos körülmények között, mesterséges fényben készült fényképek. a) Polyommatus amandus; b) Polyommatus bellargus; c) Polyommatus coridon; d) Polyommatus damon; e) Polyommatus daphnis; f) Polyommatus dorylas; g) Polyommatus icarus; h) Polyommatus semiargus; i) Polyommatus thersites

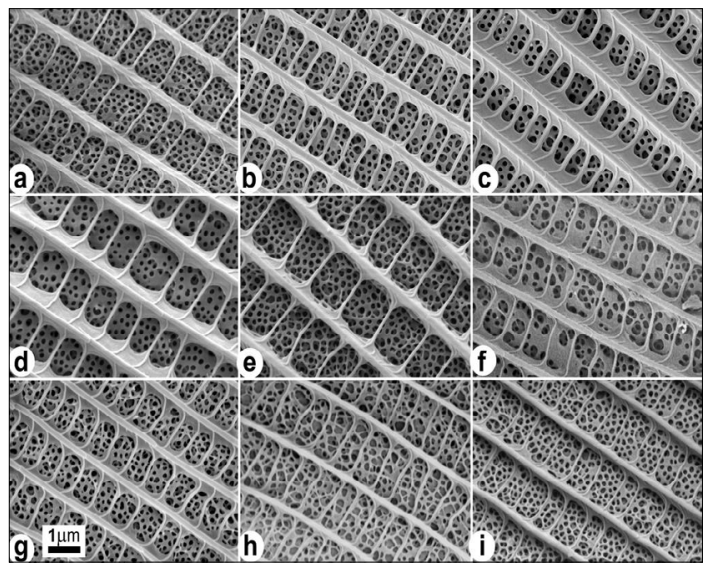

3. ábra. A 2. ábrán bemutatott kilenc lepkefaj hímjeinek jellemző pikkelyszerkezete SEM felvételeken. a) Polyommatus amandus; b) Polyommatus bellargus; c) Polyommatus coridon; d) Polyommatus damon; e) Polyommatus daphnis; f) Polyommatus dorylas; g) Polyommatus icarus; h) Polyommatus semiargus; i) Polyommatus thersites. Az alsó sor bal oldali képén megadott skála valamennyi felvételre érvényes

Jól látható a SEM-felvételeken (3. ábra), hogy valamennyi faj pikkelyei hasonló szerkezeti elvek szerint épülnek fel: a hosszanti gerinceket keresztbordák kötik össze, és az ezek alkotta háló alatt egy lyuggatott lemez helyezkedik el.

A TEM-felvételek (4. ábra) azt mutatják, hogy

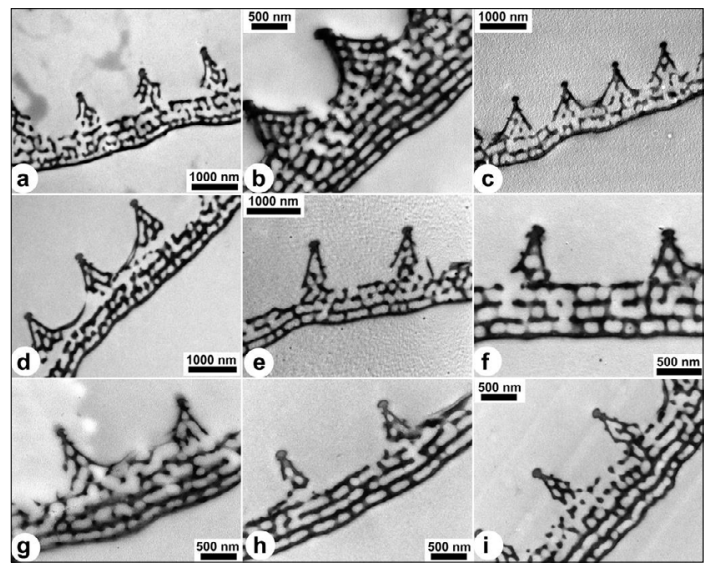

4. ábra. A 2. ábrán bemutatott kilenc lepkefaj hímjeinek jellemző pikkelyszerkezete TEM-ben. A nanoszerkezetekben a sötét részek a kitinnek felelnek meg, a világos részek a levegóvel töltött üregeknek. a) Polyommatus amandus; b) Polyommatus bellargus; c) Polyommatus coridon; d) Polyommatus damon; e) Polyommatus daphnis; f) Polyommatus dorylas; g) Polyommatus icarus; $h$ ) Polyommatus semiargus; i) Polyommatus thersites

valamennyi szerkezet sötét (kitin) és világos (levegő) rétegek váltakozásával épül fel. Eltérések főleg a rétegek számában, illetve a rétegek rendezettségében mutatkoznak. A TEM-felvételek értelmezése során nem szabad eltekinteni attól, hogy a vizsgált minta csupán $70 \mathrm{~nm}$ vastagságú. 


\section{A színek müszeres jellemzése}

A lepkeszárnyak által visszavert fény színének jellemzésére száloptikás moduláris spektrométert alkalmaztunk. Az eredményeket az 5. ábrán mutatjuk be.

Jól megfigyelhető az 5. ábrán, hogy mindegyik spektrumnak jellegzetes, eltérő jegyei vannak. Ennek tulajdonítható, hogy egy, a mesterséges neurális háló elvén működő szoftver a betanítólépések után 96\%-os pontossággal azonosította a lepkék faját a szárnyfelszínük fényvisszaverése alapján [6].

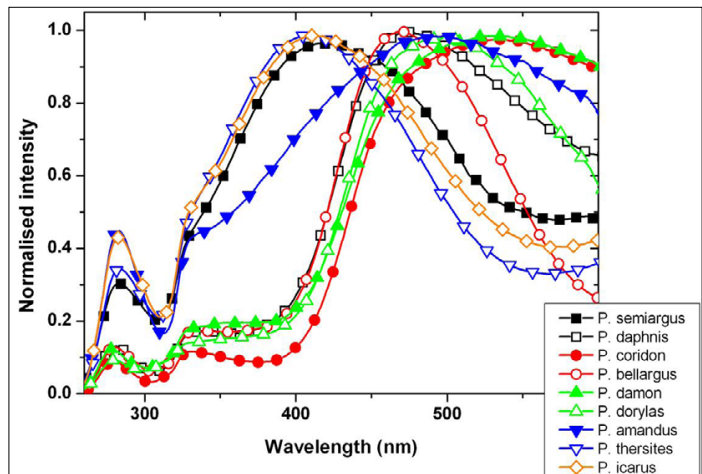

5. ábra. A kilenc megvizsgált boglárkafaj hímjeinek szárnyfelszíni fényvisszaverése. A spektrális jellemzők jobb összehasonlíthatósága miatt valamennyi görbét egyre normáltuk

\section{Következtetések}

A vizsgálataink megmutatták, hogy a boglárkalepkék kék és zöld színei szerkezeti eredetűek, olyan nanokompozitoktól erednek, amelyek két, eltérő törésmutatójú anyag: a kitin és levegő térben periodikus váltakozása útján fotonikus tiltott sávot hoznak létre. A fotonikus nanoarchitektúra a pikkelyek térfogatát tölti ki. A pikkelyek szabályos rendben borítják a szárnyak felszínét.

Az így létrehozott színek fajspecifikusak, és a szexuális kommunikációban játszanak fontos szerepet. Éppen ezért generációról generációra nagy pontossággal reprodukálódnak [10].

\section{Köszönetnyilvánítás}

A munka elvégzését a következő OTKA-támogatások tették lehetővé: 111741. és 115724.

\section{Szakirodalmi hivatkozások}

[1] Yablonovitch E.: Inhibited Spontaneous Emission in Solid-State Physics and Electronics. Physical Re- view Letters 58. (1987) 2059-2062.

https://doi.org/10.1103/PhysRevLett.58.2059

[2] John S.: Strong localization of photons in certain disordered dielectric superlattices. Physical Review Letters 58. (1987) 2486-2489.

https://doi.org/10.1103/PhysRevLett.58.2486

[3] Edagawa K., Kanoko S., Notomi M.: Photonic Amorphous Diamond Structure with a 3D Photonic Band Gap. Physical Review Letters 100. (2008) 013901.

http://doi.org/10.1103/PhysRevLett.100.013901

[4] McNamara M. E., Briggs D. E. G., Orr J. P., Wedmann S., Noh H., Cao H.: Fossilized Biophotonic Nanostructures Reveal the Original Colors of 47-Million-Year-Old Moths. PLoS Biology 9. (2011) e1001200.

https://doi.org/10.1371/journal.pbio.1001200

[5] Biró L. P., Vigneron J. P.: Photonic nanoarchitectures in butterflies and beetles: valuable sources for bioinspiration. Laser and Photonic Review 5. (2011) 27-51.

https://doi.org/10.1002/lpor.200900018

[6] Bálint Z., Kertész K., Piszter G., Vértesy Z., Biró L. P.: The well-tuned blues: the role of structural colours as optical signals in the species recognition of a local butterfly fauna (Lepidoptera: Lycaenidae: Polyommatinae). Journal of the Royal Society. Interface 9. (2012) 1745-1756.

https://doi.org/10.1098/rsif.2011.0854

[7] Biró L. P., Bálint Zs., Kertész K., Vértesy Z., Márk G. I., Horváth Z. E., Balázs J., Méhn D., Kiricsi I., Lousse V., Vigneron J.-P.. Role of photoniccrystal-type structures in the thermal regulation of a Lycaenid butterfly sister species pair. Physical Review E 67. (2003) 021907.

https://doi.org/10.1103/PhysRevE.67.021907

[8] Kertész K., Bálint Z., Vértesy Z., Márk G. I., Lousse V., Vigneron J-P., Rassart M., Biró L. P.: Gleaming and dull surface textures from photonic-crystal-type nanostructures in the butterfly Cyanophrys remus. Physical Review E 74. (2006) 021922-1-021922-15.

https://doi.org/10.1103/PhysRevE.74.021922

[9] Kertész K., Molnár G., Vértesy Z., Kóos A. A., Horváth Z. E., Márk G. I., Tapasztó L., Bálint Zs., Tamáska I., Deparis O., Vigneron J-P., Biró L. P.: Photonic band gap materials in butterfly scales: A possible source of "blueprints". Materials Science and Engineering B 149 (2008) 259-265. https://doi.org/10.1016/j.mseb.2007.10.013

[10] Kertész K., Piszter G., Bálint Z., Biró L. P.: Bio-geographical patterns in the structural blue of male Polyommatus icarus butterflies. Scientific Reports 9. (2019) 2338.

https://doi.org/10.1038/s41598-019-38827-w 